\title{
Review
}

\section{Unraveling the Relationship of Asthma and COVID-19}

\author{
Agamemnon Bakakos (D), Petros Bakakos (D) and Nikoletta Rovina*(D) \\ Department of Respiratory Medicine, National and Kapodistrian University of Athens, 11527 Athens, Greece; \\ agabak@hotmail.com (A.B.); petros44@hotmail.com (P.B.) \\ * Correspondence: nikrovina@med.uoa.gr
}

Citation: Bakakos, A.; Bakakos, P.; Rovina, N. Unraveling the Relationship of Asthma and COVID-19. J. Pers. Med. 2021, 11, 1374. https://doi.org/10.3390/ jpm11121374

Academic Editor: Lea Bentur

Received: 15 November 2021 Accepted: 13 December 2021 Published: 16 December 2021

Publisher's Note: MDPI stays neutral with regard to jurisdictional claims in published maps and institutional affiliations.

Copyright: (c) 2021 by the authors. Licensee MDPI, Basel, Switzerland. This article is an open access article distributed under the terms and conditions of the Creative Commons Attribution (CC BY) license (https:/ / creativecommons.org/licenses/by/ $4.0 /)$.

\begin{abstract}
Viral infections are one of the main causes of asthma exacerbations. During the COVID-19 era, concerns regarding the relationship of SARS-CoV2 with asthma have been raised. The concerns are both for COVID severity and asthma exacerbations. Many studies on COVID-19 epidemiology and comorbidities have assessed whether asthma represents a risk factor for SARS-CoV2 infection and/or more severe course of the disease. This review covers the current evidence on the prevalence of asthma in COVID-19 and its association with susceptibility to and severity of SARS-CoV2 infection. It will examine the possible role of underlying asthma severity in COVID-19 related outcomes as well as the molecular mechanisms involved in the co-existence of these entities. The possible role of asthma inflammatory phenotypes will also be evaluated. Finally, the impact of asthma comorbidities and the implications of asthma medication on COVID-19 will be addressed.
\end{abstract}

Keywords: Asthma; COVID-19; SARS-CoV2; immunology; asthma treatment

\section{The Prevalence of Asthma in COVID-19}

COVID-19 is a pandemic caused by coronavirus SARS-CoV2 that has so far affected 260 million people and caused almost 5.2 million deaths. Asthma is a common respiratory disease affecting almost 350 million people worldwide. It is characterized by shortness of breath, cough, chest tightness and/or wheeze that vary over time and in intensity.

There is great variation in the prevalence of asthma in the COVID-19 infected population among different countries (Table 1). This may be attributed to differences in the reporting rates, but mostly to the protective measures among respiratory disease patients, including asthmatics. The first studies coming from China demonstrated a low percentage of asthma when compared to asthma prevalence in the general population in the same areas [1-3]. The same was true for allergic comorbidities [4-6]. Later studies from Europe revealed contradictory data regarding asthma prevalence among hospitalized COVID-19 patients with some yielding low percentages $(<2 \%)$, such as in Italy, while others showed higher prevalence $(6 \%)$, such as in Spain $[7,8]$. In another study from Italy, a similarly low $(<2 \%)$ prevalence of asthma was found among COVID-19 infected patients that required treatment in an intensive care unit [9]. More recent studies from the UK and the US revealed much higher rates of asthma among COVID-19 patients. An asthma prevalence of $14.4 \%$ was found in a US COVID-19 cohort, exceeding the prevalence of the disease in the general population [10]. In the same study, the prevalence of asthma among hospitalized patients with COVID-19 was $13.5 \%$ and no significant difference in the risk of hospitalization or mortality was detected in patients with or without asthma [10]. A similar percentage of $14 \%$ in asthma prevalence among COVID-19 patients was reported in the UK [11]. 
Table 1. Studies reporting asthma prevalence in COVID-19.

\begin{tabular}{|c|c|c|c|c|}
\hline Study & Country & Study Design, Population & COVID-19 Patients $(n)$ & Asthma Prevalence \\
\hline Li X., et al. [4] & China & $\begin{array}{l}\text { Retrospective study of COVID-19 } \\
\text { patients admitted to hospital }\end{array}$ & 548 & $0.9 \%$ \\
\hline $\begin{array}{l}\text { Zhang J.J., } \\
\text { et al. [5] }\end{array}$ & China & $\begin{array}{l}\text { Retrospective study of } \\
\text { hospitalized laboratory-confirmed } \\
\text { COVID-19 patients }\end{array}$ & 290 & $0.3 \%$ \\
\hline Zhou F., et al. [6] & China & $\begin{array}{c}\text { Retrospective, multicentre cohort } \\
\text { study of hospitalized } \\
\text { laboratory-confirmed } \\
\text { COVID-19 patients }\end{array}$ & 191 & 3\% (with COPD) \\
\hline $\begin{array}{l}\text { Caminati M., } \\
\text { et al. [7] }\end{array}$ & $\begin{array}{c}\text { Italy } \\
\text { (Brescia/Verona) }\end{array}$ & $\begin{array}{l}\text { Retrospective study of } \\
\text { hospitalized COVID-19 patients in } \\
\text { two major Italian hospitals }\end{array}$ & $1043 / 305$ & $1.92 \% / 1.96 \%$ \\
\hline $\begin{array}{l}\text { Grasselli G., } \\
\text { et al. [9] }\end{array}$ & Italy & $\begin{array}{l}\text { Retrospective case series of } \\
\text { patients with } \\
\text { laboratory-confirmed COVID-19 } \\
\text { referred for ICU admission }\end{array}$ & $\begin{array}{l}1591 \text { (available data in } \\
1043 \text { patients) }\end{array}$ & $<2 \%$ \\
\hline $\begin{array}{l}\text { Borobia A.M., } \\
\text { et al. [8] }\end{array}$ & Spain & $\begin{array}{c}\text { Prospective study including } \\
\text { patients consecutively hospitalized } \\
\text { in a 1286-bed hospital of } \\
\text { Madrid (Spain) }\end{array}$ & 2226 & $5.2 \%$ \\
\hline $\begin{array}{l}\text { Chhiba K.D., } \\
\text { et al. [10] }\end{array}$ & US & $\begin{array}{l}\text { Retrospective analysis of medical } \\
\text { records of PCR-confirmed } \\
\text { COVID-19 patients }\end{array}$ & 1526 & $14 \%$ \\
\hline $\begin{array}{l}\text { Docherty A.B., } \\
\text { et al. [11] }\end{array}$ & UK & $\begin{array}{l}\text { Prospective observational cohort } \\
\text { study of hospital inpatients with } \\
\text { COVID-19, using the report form } \\
\text { developed by ISARIC and WHO }\end{array}$ & 20,133 & $14.5 \%$ \\
\hline $\begin{array}{l}\text { Lieberman- } \\
\text { Cribbin W., } \\
\text { et al. [12] }\end{array}$ & US & $\begin{array}{l}\text { Retrospective analysis of the } \\
\text { MSHS COVID-19 registry }\end{array}$ & 6250 & $4.4 \%$ \\
\hline
\end{tabular}

\section{Asthma Exacerbations in COVID-19}

Exacerbations are acute or subacute worsening of asthma symptoms that may be lifethreatening and exert a significant effect on patients' quality of life and public health [13].

Viral infections of the upper respiratory tract are one of the main causes of asthma exacerbations. Rhinoviruses are the most common cause of common cold [14] and have been more commonly related to asthma exacerbations [15]. Accordingly, the question arises as to whether SARS-CoV2 may be a cause of asthma exacerbations. Other coronaviruses are significantly less commonly reported as causes of asthma exacerbations compared to rhinovirus and RSV. It seems that SARS-CoV-2 rarely induces asthma exacerbations during hospitalization for COVID-19 [16,17].

\section{Is Asthma Associated with More Severe COVID-19 Disease?}

In one of the first studies in China—showing a very low asthma prevalence $(0.9 \%)$-no significant difference was observed in asthma prevalence between hospitalized patients with severe and non-severe COVID-19 disease [4]. A meta-analysis evaluating potential prognostic factors of mortality, which included 27 observational studies of patients with COVID-19, attempted to shed light on this topic. While particular comorbidities, such as coronary artery disease, congestive heart failure and COPD indeed increased mortality, asthma was not associated with an increased risk of severe disease and death from the novel virus [18]. Likewise, in a study from Italy, including 355 patients who eventually 
died of COVID-19, asthma was not reported among the comorbidities related to increased mortality [19]. No association was detected between asthma and mortality among COVID19 patients in a study from the Mount Sinai Health System [12]. Conclusively, there are no robust data to support that asthmatics are more likely to become severely ill when infected with SARS-CoV2, and asthma is not associated with a higher risk of mortality (Table 2). It should be kept in mind that the definition of severe asthma is not unanimous among the various populations in different studies.

Table 2. Asthma and COVID-19 severity/mortality reports.

\begin{tabular}{cccc}
\hline Study & Country & $\begin{array}{c}\text { Number (\%) of Total } \\
\text { COVID-19 Patients Enrolled }\end{array}$ & Asthma Outcome \\
\hline Li X., et al. [4] & China & $269(49.1)$ severe cases & $1.1 \%$ severe cases \\
\hline Zhou F., et al. [6] & China & 54 (28.3) deaths in hospital & $\begin{array}{c}7 \% \text { (deaths refer to chronic } \\
\text { obstructive lung disease in } \\
\text { general and not only asthma) }\end{array}$ \\
\hline Borobia A.M., et al. [8] & Spain & 460 (20.7) deaths in hospital & $3.7 \%$ deaths in hospital \\
\hline Shi C., et al. [18] & Metanalysis of 27 & 2359 (infected) & RR of asthma mortality: 3.54 \\
\hline observational studies & Italy & 355 deaths in hospital & 0 \\
\hline Lieberman-Cribbin W., et al. [12] & US & 1128 (deaths) & $4 \%$ \\
\hline
\end{tabular}

In accordance with the above, GINA suggested, in the interim guidance about COVID-19 and asthma, that people with asthma are not at increased risk of acquiring COVID-19 and that people with asthma are not at increased risk of COVID-19 related death [13].

Whether asthma severity plays a role in the risk of COVID-19 or the risk of severe COVID-19 and death is controversial. An index of asthma severity is the intensity of treatment required for asthma control. A retrospective study revealed that asthmatics treated with inhaled corticosteroids (ICS) plus long-acting beta agonists (LABA) presented a higher risk of hospitalization for COVID-19 compared to those treated only with ICS [10]. Another study, the OpenSAFELY Collaborative, demonstrated that among COVID-19 infected asthmatics, those who received high-dose ICS had a significantly higher risk of death compared to those who received combination therapy with long-acting beta-agonist (LABA) plus long-acting muscarinic agonists (LAMA) while no difference was observed in the risk of death between those who received low or medium dose ICS and those on SABA only [20]. Similarly, in patients with severe asthma on biologic therapy, no increased risk of COVID-19 infection or greater disease severity and mortality were found and no differences were detected among the different $\mathrm{mAbs}$ used for severe asthma [21,22]. Similarly, while a low asthma prevalence of $2.1 \%$ was found in an Italian cohort, including 2000 COVID-19 patients, GINA 4 and 5 step patients were more likely to have a worse outcome in this study (worse outcome defined as death, ICU admittance, and need for ventilator support) [23].

Compared to patients without asthma, asthmatics had significantly lower levels of ferritin, C-reactive protein, and lactate dehydrogenase. These laboratory markers have been used as markers of COVID-19 disease severity [10]. Such findings point towards a decreased inflammatory burden in asthmatic patients with COVID-19. However, whether this is due to the underlying asthma inflammation or due to asthma treatment is not yet clear.

Various factors, such as the definition of asthma severity that is rarely assessed in everyday clinical practice accurately, the strictness of lockdown measures and the existence of other comorbidities may contribute to differences in the incidence of COVID-19 among severe asthmatics in different countries. 
In the SANI (Severe Asthma Network in Italy), including 1504 asthmatics, 1.3\% suffered from COVID-19 and one third of them presented deterioration of asthma. In this study, severe asthmatics that were infected with SARS-CoV2 had a significantly higher prevalence of non-insulin dependent diabetes mellitus compared to those severe asthmatics that were not infected [24], indicating a role for comorbidities in SARS-CoV2 acquisition among patients with severe asthma.

\section{Asthma Phenotypes and COVID-19}

An important question arising is whether different asthma phenotypes, such as allergic and non-allergic asthma, may respond differently to the risk and severity of COVID-19 infection. A Korean cohort of 219,959 individuals of whom 7340 tested positive for SARSCoV2 revealed that asthma, as well as allergic rhinitis, were associated with an increased likelihood of a positive SARS-CoV-2 test and worse clinical outcomes, including death, ICU admission and invasive ventilation. This study also reported that individuals with non- allergic asthma were more likely to test positive for SARS-CoV2 and had a greater risk for severe outcomes of COVID-19 than those with allergic (type 2) asthma [25]. Similarly, The UK Biobank study showed that asthmatics with non-allergic asthma had a higher risk of severe COVID-19 whereas patients with allergic asthma did not experience such an elevated risk for severe COVID-19 [26]. However, none of the above mentioned studies accounted for asthma severity, which may have confounded associations. Most recently, a large longitudinal study that included 434,348 asthma and 748,327 matched patients phenotyped asthma by medication, exacerbation history, and type- 2 inflammation, using electronic medical records to identify asthma patient-level data, which were linked to Public Health England SARS-CoV-2 test data, hospital, and mortality data. This study demonstrated that patients with higher use of asthma maintenance treatment and more frequent exacerbations had significantly higher risk for severe COVID-19 outcomes, such as hospitalizations, ICU admission and death. Interestingly, no association was found between severe COVID-19 outcomes and variables representing probable type 2-inflammation, such as raised blood eosinophil count, atopy or history of allergic rhinitis [27].

\section{Allergic Asthma as a Potential Protective Factor for COVID: Mechanisms Involved}

The association of allergic asthma with viral infections (other than SARS-CoV2) has been extensively studied. A higher risk of viral infections in asthma has been associated with the lower interferon production and a synergism between allergen sensitization and viral infections in allergic asthma seems to play a role. Moreover, T2 high inflammation has been associated with impaired protection against viruses [14]. Type I interferons are antiviral cytokines that constitute the first line of defense against viruses. Most asthmatic patients are predisposed to produce lower levels of type I interferons upon respiratory viral infections, presenting a decreased defense against them. Allergic asthmatic children have increased FceRI expression on plasmacytoid dendritic cells (pDCs) and after FceRI cross-linking, they present significantly lower rhinovirus-induced IFN responses than allergic non-asthmatic and non-allergic non-asthmatic children [28,29]. pDCs from patients with asthma secreted significantly less IFN-alpha upon exposure to influenza A and secretion was inversely correlated with serum IgE levels. The crosslinking of IgE bound to FceRI diminished the influenza-induced IFN production and TLR-7 (Toll-like receptor 7) upregulation in pDCs, supporting a counter-regulation mechanism between FceRI and TLRs in pDCs and an impaired antiviral activity of pDCs upon IgE-cross-linking [30]. This deficient production of type I interferons in asthmatic patients, involving an inhibitory effect of the IgE crosslinking in pDCs has been further examined in a recent study which found that treatment with omalizumab (a mAb that blocks IgE) reduced asthma exacerbations and improved IFN- $\alpha$ responses to rhinovirus (RV). Within the omalizumab treated group, greater IFN- $\alpha$ increases were associated with fewer exacerbations [31]. Moreover, treatment with omalizumab decreased the duration of RV infection, reduced RV viral shedding and decreased susceptibility to RV infection [32]. Omalizumab also decreased the expression 
of FceR1a on pDCs, and such a decrease was linked with the restoration of RV- and influenza-induced interferon production leading to lowering asthma exacerbations [33].

SARS-CoV2 enters host cells-similarly to SARS-CoV1-via the angiotensin converting enzyme 2 (ACE2) receptor and this binding is facilitated by a transmembrane protease serine 2 (TMPRSS2). The affinity of SARS-CoV-2 for the ACE2 receptor is 10 times higher than that of SARS-CoV-1 [34]. A higher expression of ACE2 may increase the susceptibility to SARS-CoV2 infection [35]. A possible explanation for the observation that asthma and allergies are associated with reduced risk of infection and severe disease may be a reduced ACE2 gene expression in airway nasal and bronchial epithelial cells. In a study using nasal and bronchial allergen challenges, Jackson et al. [36] showed that asthma and allergic rhinitis as well as allergic sensitization were associated with reduced ACE2 gene expression. This reduction was more evident in cases of co-existence of asthma and high allergic sensitization whereas non-atopic asthma did not present reduced ACE2 expression [36]. In this way, allergic asthma, atopy and seasonal exposure to aeroallergens may protect from COVID-19.

IL-13, a type-2 cytokine, has been shown to downregulate the expression of ACE2 on airway epithelial cells in asthma and allergic rhinitis [37]. Moreover, the same study revealed a significant negative correlation of IL-4, IL-5, and IL-13 (main type-2 cytokines) with ACE2 expression in the airway epithelial cells from participants with asthma [38]. On the other hand, IL-13 was associated with an increased expression of TMPRSS2 in nasal and airway epithelial cells in type-2 asthma and atopy [37]. The association of ACE2 and TMPRSS2 gene expression with type 2 cytokines was not dependent on the effect of inhaled and/or intranasal corticosteroids in this study. Conclusively, increased expression of TMPRSS2 may counteract any protective effect of reduced ACE2 expression. Non-type 2 asthma is characterized by TH1- type responses and TH17 cell activation. It should be noted that there might be an uncoupling between ACE2 protein and RNA expression, since in a mouse model ACE2 was shown to inhibit IL-17 and neutrophilic inflammation in the lungs [39]. Data on protein levels of ACE2 is necessary in order to confirm these observations. Eventually, in the Severe Asthma Research Program cohort (SARP), sputum gene expression of ACE2 was found to be lower than TMPRSS2, but expression levels of both genes were similar in asthma and healthy controls. Asthmatics that were male, African American and had a history of diabetes mellitus presented higher expression of ACE2 and TMPRSS2. On the other hand, ICS use was associated with a lower expression of ACE2 and TMPRSS2 [40].

Eosinophils play a pivotal role in asthma pathogenesis and blood eosinophilia is a marker for T2 inflammation [41]. Eosinophils contribute to innate antiviral immunity. They express Toll-like receptors (mainly TLR7) that recognize viral nucleic acids and are activated after stimulation from single- stranded RNA, thus providing host defense against respiratory syncytial virus (RSV) [42]. Since eosinopenia has been a biomarker for the severity of COVID-19 [43], eosinophil depletion induced by anti-IL5 and anti-IL5 receptor blocking monoclonal antibodies raises concern in patients and their treating physicians, despite the lack of evidence for increased risk of COVID-19 in asthmatics treated with mepolizumab, reslizumab or benralizumab [21].

An interesting theory for explaining reduced COVID-19 severity in allergic asthma is that of heterologous immunity. Heterologous immunity may alter the immune response to an infection with a pathogen as a consequence of a previous infection with another pathogen [44]. This may happen between closely related or completely unrelated antigens. In case of protein sequence homology between SARS-CoV2 and allergens, it is possible that cross-reactive T-cell epitopes are generated. In this way, patients with allergic asthma may carry in their T-cell repertoire $\mathrm{T}$ cells that are cross-reactive to SARS-CoV-2 and allergens. This may yield an advantage for patients with allergic asthma when infected with SARS-CoV-2. More studies are needed to support or refute this attractive theory.

In contrast to allergic asthma, non-type 2 asthma involves the activation of neutrophils, which drives the immune response toward a TH1/TH17 response [45]. Patients with 
COVID-19 present an immune response polarized toward a classic TH1 response, and the comorbidity of non-allergic asthma might aggravate such TH1 immune response. It has already been shown that there is a positive correlation between ACE2 gene expression and IL-17 (TH17) gene expression which may facilitate SARS-CoV2 infection [38]. Additionally, TH1/TH17 cytokines such as TNF, IL-12, and IL-17A can upregulate ACE2 expression [46]. Asthmatics with this endotype suffer more often from comorbidities, such as obesity, diabetes mellitus and hypertension [2], and it has already been mentioned that some of these comorbidities are associated with a higher expression of ACE2 and TMPRSS2 [40]. Eventually, patients with non-type 2 asthma present a low number of blood eosinophils and this may preclude the contribution of these cells to combat SARS-CoV-2 [47].

Although there are data to support an interplay of asthma phenotypes and underlying mechanisms with COVID-19, the majority of the so far published studies are retrospective and do not discriminate asthmatic patients into phenotypes. Better pheno/endotyping of patients with asthma and COVID-19 is required if we want to define more precisely the immunologic links between these two diseases.

\section{Implications of Asthma Treatment on COVID-19}

There is increased interest on the adverse effects of asthma treatment on COVID-19 patients. It is well known that ICS are the mainstay of asthma treatment, while systemic corticosteroids are frequently used in severe refractory asthma and in the exacerbations of the disease. Currently, the suggestion for asthma and COPD COVID-19 patients receiving ICS is to carry on with their treatment [13].

However, the remaining question is whether premorbid use or chronic treatment with ICS is of benefit. Halpin et al. [48] did not reach a clear-cut conclusion on this question in their systematic review of patients with coronavirus acute respiratory infections (MERS, SARS and COVID-19). There is no definite association between ICS treatment and susceptibility to viral infections, on the contrary there are reports of a paradoxical protection against viral infections $[49,50]$. Specifically, ciclesonide has been shown to block SARS-CoV2 replication in vitro, inhibiting its cytopathogenicity [51,52]. This was indirectly supported in the study of Iwabuchi et al. [53] who showed an improvement of COVID-19 patients on oxygen therapy after treatment with inhaled ciclesonide. Antiviral and anti-inflammatory properties in vitro are reported for budesonide as well [54]. In an open-label, parallel group, phase 2 randomized control trial [55] in mild outpatient COVID19 patients, those who received inhaled budesonide had a 91\% relative risk reduction in COVID-19-related emergency department visits or hospitalization as compared to the standard of care. On the other hand, Schultze et al. [20] reported increased risk of mortality in asthma patients receiving high-dose ICS, acknowledging however, that this finding could be attributed to several confounders.

Presently, there is cumulative evidence on the effects and safety of systemic corticosteroids on COVID-19 patients with or without concomitant asthma, after the positive results of the RECOVERY trial [56]. The National Institutes of Health (NIH), COVID-19 Treatment Guidelines and the World Health Organization (WHO) recommend dexamethasone treatment in hospitalized patients with respiratory failure requiring non-invasive/High flow oxygen device or invasive ventilation [57]. Several studies have associated systemic corticosteroid treatment with increased viral load, immune suppression, prolonged viral shedding, delayed viral clearance, and increased mortality [58-61]. However, there is scarce data on the effect of systemic corticosteroids on COVID-19 in asthma patients. Chhiba et al. [10] did not show any association between systemic corticosteroid use and COVID19-related hospitalization. However, other studies demonstrated that chronic or recurrent systemic corticosteroid use relates with increased risk for severe COVID-19 and higher mortality. Using primary care electronic medical records, Williamson et al. [62] reported that COVID-19 patients with severe asthma having a recent use of systemic corticosteroids had increased mortality risk. More recently, Adir et al. [63] in a large nationwide study that included 80,602 asthma patients showed that systemic corticosteroids use was an 
independent risk factor for more severe COVID-19 and higher all cause 90-day mortality. However, they did not find a higher risk of viral infection in patients treated with systemic corticosteroids or biologics. These observations suggest that the more severe asthma is, the higher the risk of developing severe COVID-19 disease and the possibility to experience a worse outcome.

Biologic treatment (omalizumab, an anti-immunoglobulin E (IgE) antibody; mepolizumab and reslizumab, which block interleukin IL-5; benralizumab, which blocks the IL-5 receptor; and dupilumab, which blocks IL-4 receptor $\alpha$, a receptor shared by IL-4 and IL-13) have all been approved for the treatment of severe asthma and have been shown to be effective in reducing symptoms and asthma-related exacerbations.

In the face of the COVID-19 pandemic, two major concerns on the safety of the biologics are raised. Firstly, is there higher susceptibility of SARS-CoV2 infection in asthma patients that receive biologic therapy? Secondly, once infected, how would the biologic treatment affect the severity and outcome of COVID-19? Published data on the effects of biologic therapy on the risk of COVID-19 are controversial (Table 3).

Table 3. COVID-19 and severe asthma on biologic therapy.

\begin{tabular}{|c|c|c|c|c|c|}
\hline Study & Country & $\begin{array}{l}\text { Asthma Patients on } \\
\text { Biologic Therapy }(n)\end{array}$ & $\begin{array}{l}\text { Asthma Patients on } \\
\text { Biologic Therapy } \\
\text { and COVID-19 }(n-\%)\end{array}$ & $\begin{array}{c}\text { Hospital } \\
\text { Admissions * } \\
(n-\%)\end{array}$ & Deaths $(n)$ \\
\hline Rial M.J., et al. [19] & Spain & 545 & $35-6.4 \%$ & $8-22.9 \%$ & 1 \\
\hline Heffler E., et al. [21] & Belgium & 434 & $11-2.5 \%$ & $4-36.3 \%$ & 0 \\
\hline Adir Y., et al. [63] & Israel & 8242 & $50-0.6 \%$ & - & $\begin{array}{c}\text { HR of all-cause } \\
\text { mortality } \\
\text { within } 90 \text { days } \\
\text { following PCR: } \\
1.42(0.70-2.88)\end{array}$ \\
\hline Izquierdo J.L., et al. [64] & Spain & 865 & $20-2.3 \%$ & $2-10 \%$ & 1 \\
\hline Ferastraoaru D., et al. [65] & US & - & $8-0.8 \%$ & $6-1 \%$ & - \\
\hline
\end{tabular}

* Number and percentage of hospital admissions among those with severe asthma under biologic therapy that were infected with SARS-CoV2.

In a large study from Spain, including 545 severe asthmatics under biologic treatment, no increased risk of COVID-19 infection or greater disease severity and mortality was found and no differences were detected among the different mAbs used for severe asthma [21].

In a Belgian cohort, a low incidence of COVID-19 infection in severe asthma patients $(2.1 \%)$ was noted and no severe disease or death occurred [22]. In accordance with the previous study, the use of biologics for severe allergic or severe eosinophilic asthma was not associated with a higher risk of COVID-19 [22]. In addition, Adir et al. [63] showed that severe asthma patients on biologic treatment were not at higher risk of SARS-CoV-2 infection, as compared with asthmatic patients that were not on biologic therapy. In contrast, two recent studies suggested a higher susceptibility of viral infection, especially in severe asthma patients on biologic treatment [63,65].

Biologic treatment may act protectively via several pathways. Omalizumab prevents IgE from binding to its receptor on plasmacytoid dendritic cells, leading to lower IFN-1 production by cross-linking of $\mathrm{IgE}$, and to a decreased risk of duration, and viral shedding of human rhinovirus in children with allergy [28]. Furthermore, mepolizumab, reslizumab and benralizumab may also play a protective role in enhancing immune responses to viral infections, given that a higher ratio of IFN- $\gamma / \mathrm{IL}-5 \mathrm{mRNA}$ is associated with lower viral shedding and faster clearance [66]. In addition, low eosinophil counts in peripheral blood may be related to the infection with the SARS-CoV-2 virus itself, and not necessarily be an indicator that treatments, which reduce eosinophil counts in patients with asthma. would be associated with in more severe COVID-19 disease. Interestingly, eosinopenia is not reported in patients with severe COVID-19 in recent studies from Italy and China $[4,8,67]$. 
Dupilumab, which blocks IL-4 receptor $\alpha$, a receptor shared by IL-4 and IL-13, leads to decreased airway inflammation, allergic hyperresponsiveness and asthma exacerbations. Interleukin 4 is essential for antibody switching to IgE. Additionally, IL-13 is involved in airway hyperresponsiveness and remodeling, factors that are involved in susceptibility and clearance of lower airway viral infections [68]. Indeed, clinical trials with dupilumab do not report increased risk for viral respiratory infections $[69,70]$. In contrast, it is likely that dubilumab will rather lessen the risk of severe asthma exacerbations in patients with COVID-19, at least by reducing baseline airway inflammation, possibly through specific antiviral properties.

Collectively, based on the current knowledge, it seems that biologic therapy for severe asthma rather acts protectively by limiting Th2 skewing, and preparing the immune system better poised to clear SARS-CoV-2.

\section{Conclusions}

The prevalence of asthma in the COVID-19 infected population varies among different studies and countries. It seems that people with allergic asthma are not at increased risk of SARS-CoV2 infection and not at increased risk of COVID-19 related death. Additionally, underlying asthma severity is not a determinant of COVID-19 outcomes. In accordance, patients with severe asthma receiving biologic therapy presented neither increased risk of COVID-19 infection nor greater disease severity and mortality. Severe asthmatics should continue their regular maintenance treatment with ICS and even biologics in the COVID-19 era. Non-allergic asthma seems to present a greater risk for severe COVID-19 outcomes compared to allergic asthma. There are several potential mechanisms explaining why allergic asthma and atopy may be associated with reduced risk of infection and severe disease and on the other hand why non-allergic asthma may confer worse outcomes. Better endotyping of patients with asthma that are infected with SARS-CoV2 is of utmost importance in order to elucidate the immunologic links between these two diseases.

Author Contributions: Conceptualization, N.R. and P.B.; Methodology: N.R. and P.B.; Writing, A.B., P.B. and N.R.; Original draft preparation: A.B., P.B. and N.R.; Writing review: P.B. and N.R. All authors have read and agreed to the published version of the manuscript.

Funding: There was no funding for this work.

Institutional Review Board Statement: Not applicable.

Informed Consent Statement: Not applicable.

Conflicts of Interest: The authors declare no conflict of interest.

\section{References}

1. Guan, W.J.; Ni, Z.Y.; Hu, Y.; Liang, W.H.; Ou, C.Q.; He, J.X.; Liu, L.; Shan, H.; Lei, C.-L.; Hui, D.S.C.; et al. Clinical Characteristics of Coronavirus Disease 2019 in China. N. Engl. J. Med. 2020, 382, 1708-1720. [CrossRef]

2. Huang, C.; Wang, Y.; Li, X.; Ren, L.; Zhao, J.; Hu, Y.; Zhang, L.; Fan, G.; Xu, J.; Gu, X.; et al. Clinical features of patients infected with 2019 novel coronavirus in Wuhan, China. Lancet 2020, 395, 497-506. [CrossRef]

3. Chen, N.; Zhou, M.; Dong, X.; Qu, J.; Gong, F.; Han, Y.; Qiu, Y.; Wang, J.; Liu, Y.; Wei, Y.; et al. Epidemiological and clinical characteristics of 99 cases of 2019 novel coronavirus pneumonia in Wuhan, China: A descriptive study. Lancet 2020, 395, 507-513. [CrossRef]

4. Li, X.; Xu, S.; Yu, M.; Wang, K.; Tao, Y.; Zhou, Y.; Shi, J.; Zhou, M.; Wu, B.; Yang, Z.; et al. Risk factors for severity and mortality in adult COVID-19 inpatients in Wuhan. J. Allergy Clin. Immunol. 2020, 146, 110-118. [CrossRef] [PubMed]

5. Zhang, J.J.; Cao, Y.Y.; Dong, X.; Wang, B.C.; Liao, M.Y.; Lin, J.; Yan, Y.-G.; Akdis, C.A.; Gao, Y.-D. Distinct characteristics of COVID-19 patients with initial rRT-PCR-positive and rRT-PCR-negative results for SARS-CoV-2. Allergy 2020, in press. [CrossRef] [PubMed]

6. Zhou, F.; Yu, T.; Du, R.; Fan, G.; Liu, Y.; Liu, Z.; Xiang, J.; Wang, Y.; Song, B.; Gu, X.; et al. Clinical course and risk factors for mortality of adult inpatients with COVID-19 in Wuhan, China: A retrospective cohort study. Lancet 2020, 395, 1054-1062. [CrossRef]

7. Caminati, M.; Lombardi, C.; Micheletto, C.; Roca, E.; Bigni, B.; Furci, F.; Girelli, D.; Senna, G.; Crisafulli, E. Asthmatic patients in COVID-19 outbreak: Few cases despite many cases. J. Allergy Clin. Immunol. 2020, 146, 541-542. [CrossRef] [PubMed] 
8. Borobia, A.; Carcas, A.; Arnalich, F.; Álvarez-Sala, R.; Monserrat-Villatoro, J.; Quintana, M.; Figueira, J.; Santos-Olmo, R.T.; García-Rodríguez, J.; Martín-Vega, A.; et al. A Cohort of Patients with COVID-19 in a Major Teaching Hospital in Europe. J. Clin. Med. 2020, 9, 1733. [CrossRef]

9. Grasselli, G.; Zangrillo, A.; Zanella, A.; Antonelli, M.; Cabrini, L.; Castelli, A.; Cereda, D.; Coluccello, A.; Foti, G.; Fumagalli, R.; et al. Baseline Characteristics and Outcomes of 1591 Patients Infected with SARS-CoV-2 Admitted to ICUs of the Lombardy Region, Italy. JAMA 2020, 323, 1574-1581. [CrossRef]

10. Chhiba, K.D.; Patel, G.B.; Vu, T.H.T.; Chen, M.M.; Guo, A.; Kudlaty, E.; Mai, Q.; Yeh, C.; Muhammad, L.N.; Harris, K.E.; et al. Prevalence and characterization of asthma in hospitalized and nonhospitalized patients with COVID-19. J. Allergy Clin. Immunol. 2020, 146, 307.e4-314.e4. [CrossRef]

11. Docherty, A.B.; Harrison, E.M.; Green, C.A.; Hardwick, H.E.; Pius, R.; Norman, L.; Holden, K.A.; Read, J.M.; Dondelinger, F.; Carson, G.; et al. Features of 20133 UK patients in hospital with COVID-19 using the ISARIC WHO Clinical Characterisation Protocol: Prospective observational cohort study. BMJ 2020, 369, m1985. [CrossRef]

12. Lieberman-Cribbin, W.; Rapp, J.; Alpert, N.; Tuminello, S.; Taioli, E. The Impact of Asthma on Mortality in Patients With COVID-19. Chest 2020, 158, 2290-2291. [CrossRef]

13. Global Initiative for Asthma. Global Strategy for Asthma Management and Prevention. 2020. Available online: http://www. ginasthma.org (accessed on 1 April 2021).

14. Busse, W.W.; Lemanske, R.F., Jr.; E Gern, J. Role of viral respiratory infections in asthma and asthma exacerbations. Lancet 2010, 376, 826-834. [CrossRef]

15. Zambrano, J.C.; Carper, H.T.; Rakes, G.P.; Patrie, J.; Murphy, D.D.; Platts-Mills, T.A.; Hayden, F.G.; Gwaltney, J.M.; Hatley, T.K.; Owens, A.M.; et al. Experimental rhinovirus challenges in adults with mild asthma: Response to infection in relation to IgE. J. Allergy Clin. Immunol. 2003, 111, 1008-1016. [CrossRef]

16. Greenberg, S.B. Update on Human Rhinovirus and Coronavirus Infections. Semin. Respir. Crit. Care Med. 2016, 37, 555-571. [CrossRef] [PubMed]

17. Garg, S.; Kim, L.; Whitaker, M.; O’Halloran, A.; Cummings, C.; Holstein, R.; Prill, M.; Chai, S.J.; Kirley, P.D.; Alden, N.B.; et al. Hospitalization Rates and Characteristics of Patients Hospitalized with Laboratory-Confirmed Coronavirus Disease 2019-COVID-NET, 14 States, March 1-30, 2020. MMWR Morb. Mortal. Weekl. Rep. 2020, 69, 458-464. [CrossRef]

18. Shi, C.; Wang, L.; Ye, J.; Gu, Z.; Wang, S.; Xia, J.; Xie, Y.; Li, Q.; Xu, R.; Lin, N. Predictors of mortality in patients with coronavirus disease 2019: A systematic review and meta-analysis. BMC Infect. Dis. 2021, 21, 663. [CrossRef] [PubMed]

19. Onder, G.; Rezza, G.; Brusaferro, S. Case-Fatality Rate and Characteristics of Patients Dying in Relation to COVID-19 in Italy. JAMA 2020, 323, 1775-1776. [CrossRef] [PubMed]

20. The OpenSAFELY Collaborative; Schultze, A.; Walker, A.J.; MacKenna, B.; Morton, C.E.; Bhaskaran, K.; Brown, J.P.; Rentsch, C.T.; Williamson, E.; Drysdale, H.; et al. Inhaled corticosteroid use and risk COVID-19 related death among 966,461 patients with COPD or asthma: An OpenSAFELY analysis. medRxiv 2020. [CrossRef]

21. Rial, M.J.; Valverde, M.; del Pozo, V.; González-Barcala, F.J.; Martínez-Rivera, C.; Muñoz, X.; Olaguibel, J.M.; Plaza, V.; Curto, E.; Quirce, S.; et al. Clinical characteristics in 545 patients with severe asthma on biological treatment during the COVID-19 outbreak. J. Allergy Clin. Immunol. Pr. 2020, 9, 487.e1-489.e1. [CrossRef]

22. Hanon, S.; Brusselle, G.; Deschampheleire, M.; Louis, R.; Michils, A.; Peché, R.; Pilette, C.; Rummens, P.; Schuermans, D.; Simonis, H.; et al. COVID-19 and biologics in severe asthma: Data from the Belgian Severe Asthma Registry. Eur. Respir. J. 2020, 56, 2002857. [CrossRef] [PubMed]

23. Caminati, M.; Vultaggio, A.; Matucci, A.; Senna, G.; Almerigogna, F.; Bagnasco, D.; Chieco-Bianchi, F.; Cosini, F.; Girelli, D.; Guarnieri, G.; et al. Asthma in a large COVID-19 cohort: Prevalence, features, and determinants of COVID-19 disease severity. Respir. Med. 2020, 176, 106261. [CrossRef] [PubMed]

24. Heffler, E.; Detoraki, A.; Contoli, M.; Papi, A.; Paoletti, G.; Malipiero, G.; Brussino, L.; Crimi, C.; Morrone, D.; Padovani, M.; et al. COVID-19 in Severe Asthma Network in Italy (SANI) patients: Clinical features, impact of comorbidities and treatments. Allergy 2021, 76, 887-892. [CrossRef]

25. Yang, J.M.; Koh, H.Y.; Moon, S.Y.; Yoo, I.K.; Ha, E.K.; You, S.; Ha, E.K.; You, S.; Kim, S.Y.; Yon, D.K.; et al. Allergic disorders and susceptibility to and severity of COVID-19: A nationwide cohort study. J. Allergy Clin. Immunol. 2020, 146, 790-798. [CrossRef]

26. Zhu, Z.; Hasegawa, K.; Ma, B.; Fujiogi, M.; Camargo, C.A., Jr.; Liang, L. Association of asthma and its genetic predisposition with the risk of severe COVID-19. J. Allergy Clin. Immunol. 2020, 146, 327-329.e4. [CrossRef]

27. Bloom, C.I.; Cullinan, P.; Wedzicha, J.A. Asthma Phenotypes and COVID-19 Risk: A Population-based Observational Study. Am. J. Respir. Crit. Care Med. 2021. [CrossRef]

28. Durrani, S.R.; Montville, D.J.; Pratt, A.S.; Sahu, S.; DeVries, M.K.; Rajamanickam, V.; Gangnon, R.E.; Gill, M.A.; Gern, J.E.; Lemanske, R.F., Jr.; et al. Innate immune responses to rhinovirus are reduced by the high-affinity IgE receptor in allergic asthmatic children. J. Allergy Clin. Immunol. 2012, 130, 489-495. [CrossRef]

29. Wark, P.A.; Johnston, S.; Bucchieri, F.; Powell, R.; Puddicombe, S.; Laza-Stanca, V.; Holgate, S.T.; Davies, D.E. Asthmatic bronchial epithelial cells have a deficient innate immune response to infection with rhinovirus. J. Exp. Med. 2005, 201, 937-947. [CrossRef]

30. Gill, M.A.; Bajwa, G.; George, T.A.; Dong, C.C.; Dougherty, I.I.; Jiang, N.; Gan, V.N.; Gruchalla, R.S. Counterregulation between the FcepsilonRI pathway and antiviral responses in human plasmacytoid dendritic cells. J. Immunol. 2010, 184, 5999-6006. [CrossRef] 
31. Teach, S.J.; Gill, M.A.; Togias, A.; Sorkness, C.A.; Arbes, S.J.; Calatroni, A.; Wildfire, J.J.; Gergen, P.J.; Cohen, R.; Pongracic, J.A.; et al. Preseasonal treatment with either omalizumab or an inhaled corticosteroid boost to prevent fall asthma exacerbations. $J$. Allergy Clin. Immunol. 2015, 136, 1476-1485. [CrossRef] [PubMed]

32. Esquivel, A.; Busse, W.W.; Calatroni, A.; Togias, A.G.; Grindle, K.G.; Bochkov, Y.A.; Gruchalla, R.S.; Kattan, M.; Kercsmar, C.M.; Hershey, G.K.; et al. Effects of Omalizumab on Rhinovirus Infections, Illnesses, and Exacerbations of Asthma. Am. J. Respir. Crit. Care Med. 2017, 196, 985-992. [CrossRef]

33. Gill, M.A.; Liu, A.H.; Calatroni, A.; Krouse, R.Z.; Shao, B.; Schiltz, A.; Gern, J.E.; Togias, A.; Busse, W.W. Enhanced plasmacytoid dendritic cell antiviral responses after omalizumab. J. Allergy Clin. Immunol. 2018, 141, 1735.e9-1743.e9. [CrossRef]

34. Wrapp, D.; Wang, N.; Corbett, K.S.; Goldsmith, J.A.; Hsieh, C.-L.; Abiona, O.; Graham, B.S.; McLellan, J.S. Cryo-EM structure of the 2019-nCoV spike in the prefusion conformation. Science 2020, 367, 1260-1263. [CrossRef] [PubMed]

35. Jia, H.P.; Look, D.C.; Shi, L.; Hickey, M.; Pewe, L.; Netland, J.; Farzan, M.; Wohlford-Lenane, C.; Perlman, S.; McCray, P.B., Jr. ACE2 Receptor Expression and Severe Acute Respiratory Syndrome Coronavirus Infection Depend on Differentiation of Human Airway Epithelia. J. Virol. 2005, 79, 14614-14621. [CrossRef] [PubMed]

36. Jackson, D.J.; Busse, W.W.; Bacharier, L.B.; Kattan, M.; O'Connor, G.T.; Wood, R.A.; Visness, C.M.; Durham, S.R.; Larson, D.; Esnault, S.; et al. Association of respiratory allergy, asthma, and expression of the SARS-CoV-2 receptor ACE2. J. Allergy Clin. Immunol. 2020, 146, 203.e3-206.e3. [CrossRef]

37. Kimura, H.; Francisco, D.; Conway, M.; Martinez, F.D.; Vercelli, D.; Polverino, F.; Wenzel, S.E.; Siddiqui, S. Type 2 inflammation modulates ACE2 and TMPRSS2 in airway epithelial cells. J. Allergy Clin. Immunol. 2020, 146, 80.e8-88.e8. [CrossRef] [PubMed]

38. Bradding, P.; Richardson, M.; Hinks, T.S.; Howarth, P.H.; Choy, D.F.; Arron, J.R.; Wenzel, S.E.; Siddiqui, S. ACE2, TMPRSS2, and furin gene expression in the airways of people with asthma-implications for COVID-19. J. Allergy Clin. Immunol. 2020, 146, 208-211. [CrossRef]

39. Sodhi, C.P.; Nguyen, J.; Yamaguchi, Y.; Werts, A.D.; Lu, P.; Ladd, M.R.; Fulton, W.B.; Kovler, M.L.; Wang, S.; Prindle, T., Jr.; et al. A Dynamic Variation of Pulmonary ACE2 Is Required to Modulate Neutrophilic Inflammation in Response to Pseudomonas aeruginosa Lung Infection in Mice. J. Immunol. 2019, 203, 3000-3012. [CrossRef]

40. Peters, M.C.; Sajuthi, S.; Deford, P.; Christenson, S.; Rios, C.L.; Montgomery, M.T.; Woodruff, P.G.; Mauger, D.T.; Erzurum, S.C.; Johansson, M.W.; et al. COVID-19-related Genes in Sputum Cells in Asthma. Relationship to Demographic Features and Corticosteroids. Am. J. Respir. Crit. Care Med. 2020, 202, 83-90. [CrossRef]

41. Woodruff, P.G.; Modrek, B.; Choy, D.; Jia, G.; Abbas, A.R.; Ellwanger, A.; Koth, L.L.; Arron, J.R.; Fahy, J.V. T-helper Type 2-driven Inflammation Defines Major Subphenotypes of Asthma. Am. J. Respir. Crit. Care Med. 2009, 180, 388-395. [CrossRef]

42. Phipps, S.; Lam, C.E.; Mahalingam, S.; Newhouse, M.; Ramirez, R.; Rosenberg, H.F.; Foster, P.S.; Matthaei, K.I. Eosinophils contribute to innate antiviral immunity and promote clearance of respiratory syncytial virus. Blood 2007, 110, 1578-1586. [CrossRef] [PubMed]

43. Zhang, J.J.; Dong, X.; Cao, Y.Y.; Yuan, Y.D.; Yang, Y.B.; Yan, Y.Q.; Akdis, C.A.; Gao, Y.D. Clinical characteristics of 140 patients infected with SARS-CoV-2 in Wuhan, China. Allergy 2020, 75, 1730-1741. [CrossRef]

44. Welsh, R.M.; Selin, L. No one is naive: The significance of heterologous T-cell immunity. Nat. Rev. Immunol. 2002, 2, 417-426. [CrossRef]

45. Amin, K.; Lúdvíksdóttir, D.; Janson, C.; Nettelbladt, O.; Björnsson, E.; Roomans, G.M.; Boman, G.; Seveus, L.; Venge, P. Inflammation and Structural Changes in the Airways of Patients with Atopic and Nonatopic Asthma. Am. J. Respir. Crit. Care Med. 2000, 162, 2295-2301. [CrossRef]

46. Song, X.; Hu, W.; Yu, H.; Zhao, L.; Zhao, Y.; Zhao, X.; Xue, H.H.; Zhao, Y. Little to no expression of angiotensin-converting enzyme-2 on most human peripheral blood immune cells but highly expressed on tissue macrophages. Cytom. Part A 2020. [CrossRef]

47. Esteban-Gorgojo, I.; Antolín-Amérigo, D.; Domínguez-Ortega, J.; Quirce, S. Non-eosinophilic asthma: Current perspectives. J. Asthma Allergy 2018, 11, 267-281. [CrossRef]

48. Halpin, D.M.G.; Singh, D.; Hadfield, R.M. Inhaled corticosteroids and COVID-19: A systematic review and clinical perspective. Eur. Respir. J. 2020, 55, 2001009. [CrossRef]

49. Yang, I.A.; Clarke, M.S.; Sim, E.H.A.; Fong, K.M. Inhaled corticosteroids for stable chronic obstructive pulmonary disease. Cochrane Database Syst. Rev. 2012, 7, CD002991. [CrossRef] [PubMed]

50. Contoli, M.; Pauletti, A.; Rossi, M.R.; Spanevello, A.; Casolari, P.; Marcellini, A.; Forini, G.; Gnesini, G.; Marku, B.; Barnes, N.; et al. Long-term effects of inhaled corticosteroids on sputum bacterial and viral loads in COPD. Eur. Respir. J. 2017, 50, 1700451. [CrossRef]

51. Matsuyama, S.; Kawase, M.; Nao, N.; Shirato, K.; Ujike, M.; Kaminati, W.; Shimojima, M.; Fukushi, S. The Inhaled Steroid Ciclesonide Blocks SARS-CoV-2 RNA Replication by Targeting the Viral Replication-Transcription Complex in Cultured Cells. J. Virol. 2020, 95, e01648-20. [CrossRef] [PubMed]

52. Jeon, S.; Ko, M.; Lee, J.; Choi, I.; Byun, S.Y.; Park, S.; Shum, D.; Kim, S. Identification of antiviral drug candidates against SARS-CoV2 from FDA-approved drugs. Antimicrob. Agents Chemother. 2020, 64, e00819-20. [CrossRef]

53. Iwabuchi, K.; Yoshie, K.; Kurakami, Y.; Takahashi, K.; Kato, Y.; Morishima, T. Therapeutic potential of ciclesonide inahalation for COVID-19 pneumonia: Report of three cases. J. Infect. Chemother. 2020, 26, 625-632. [CrossRef] 
54. Yamaya, M.; Nishimura, H.; Deng, X.; Sugawara, M.; Watanabe, O.; Nomura, K.; Shimotai, Y.; Momma, H.; Ichinose, M.; Kawase, T. Inhibitory effects of glycopyrronium, formoterol, and budesonide on coronavirus HCoV-229E replication and cytokine production by primary cultures of human nasal and tracheal epithelial cells. Respir. Investig. 2020, 58, 155-168. [CrossRef]

55. Ramakrishnan, S.; Nicolau, D.V., Jr.; Langford, B. Inhaled budesonide in the treatment of early COVID-19 (STOIC): A phase 2, open-label randomized controlled trial. Lancet 2021, 9, 763-772. [CrossRef]

56. The RECOVERY Collaborative Group. Dexamethasone in Hospitalized Patients with COVID-19. N. Engl. J. Med. 2021, 384, 693-704. [CrossRef]

57. World Health Organization. WHO Welcomes Preliminary Results about Dexamethasone Use in Treating Critically Ill COVID-19 Patients. Available online: https:/ / www.ncbi.nlm.nih.gov/pmc/articles/PMC7599121/ (accessed on 18 June 2020).

58. Gong, Y.; Guan, L.; Jin, Z.; Chen, S.; Xiang, G.; Gao, B. Effects of methylprednisolone on viral genomic nucleic acid negative conversion and CT imaging lesion absorption in COVID-19 patients under 50 years old. J. Med. Virol. 2020, 92, 2551. [CrossRef] [PubMed]

59. Salton, F.; Confalonieri, P.; Meduri, G.U.; Santus, P.; Harari, S.; Scala, R.; Lanini, S.; Vertui, V.; Oggioni, T.; Caminati, A.; et al. Prolonged Low-Dose Methylprednisolone in Patients With Severe COVID-19 Pneumonia. Open Forum Infect. Dis. 2020, 7, ofaa421. [CrossRef] [PubMed]

60. Wu, C.; Hou, D.; Du, C.; Cai, Y.; Zheng, J.; Xu, J.; Chen, X.; Chen, C.; Hu, X.; Zhang, Y.; et al. Corticosteroid therapy for coronavirus disease 2019-related acute respiratory distress syndrome: A cohort study with propensity score analysis. Crit. Care 2020, 24, 643. [CrossRef]

61. Yuan, M.; Xu, X.; Xia, D.; Tao, Z.; Yin, W.; Tan, W.; Hu, Y.; Song, C. Effects of Corticosteroid Treatment for Non-Severe COVID-19 Pneumonia: A Propensity Score-Based Analysis. Shock 2020, 54, 638-643. [CrossRef]

62. Williamson, E.J.; Walker, A.J.; Bhaskaran, K.; Bacon, S.; Bates, C.; Morton, C.E.; Curtis, H.J.; Mehrkar, A.; Evans DMInglesby, P.; Cockburn, J.; et al. Factors associated with COVID-19-related death using OpenSAFELY. Nature 2020, 584, 430-436. [CrossRef] [PubMed]

63. Adir, Y.; Humbert, M.; Saliba, W. COVID-19 risk and outcomes in adult asthmatic patients treated with biologics or systemic corticosteroids: Nationwide real-world evidence. J. Allergy Clin. Immunol. 2021, 148, 361.e13-367.e13. [CrossRef] [PubMed]

64. Izquierdo, J.L.; Almonacid, C.; González, Y.; Del Rio-Bermudez, C.; Ancochea, J.; Cárdenas, R.; Lumbreras, S.; Soriano, J.B. The impact of COVID-19 on patients with asthma. Eur. Respir. J. 2021, 57, 2003142. [CrossRef]

65. Ferastraoaru, D.; Hudes, G.; Jerschow, E.; Jariwala, S.; Karagic, M.; de Vos, G.; Rosenstreich, D.; Ramesh, M. Eosinophilia in Asthma Patients Is Protective Against Severe COVID-19 Illness. J. Allergy Clin. Immunol. Pr. 2021, 9, 1152.e3-1162.e3. [CrossRef] [PubMed]

66. Gern, J.E.; Vrtis, R.; Grindle, K.A.; Swenson, C.; Busse, W.W. Relationship of upper and lower airway cytokines to outcome of experimental rhinovirus infection. Am. J. Respir. Crit. Care Med. 2000, 162, 2226-2231. [CrossRef]

67. Zhu, J.; Ji, P.; Pang, J.; Zhong, Z.; Li, H.; He, C.; Zhang, J.; Zhao, C. Clinical characteristics of 3062 COVID-19 patients: A metaanalysis. J. Med. Virol. 2020, 92, 1902-1914. [CrossRef] [PubMed]

68. Agache, I.; Song, Y.; Rocha, C.; Beltran, J.; Posso, M.; Steiner, C.; Alonso-Coello, P.; Akdis, C.; Akdis, M.; Canonica, G.W.; et al. Efficacy and safety of treatment with dupilumab for severe asthma: A systematic review of the EAACI guidelinesRecommendations on the use of biologicals in severe asthma. Allergy 2020, 75, 1058-1068. [CrossRef]

69. Eichenfield, L.F.; Bieber, T.; Beck, L.A.; Simpson, E.L.; Thaçi, D.; de Bruin-Weller, M.; Deleuran, M.; Silverberg, J.I.; Ferrandiz, C.; Fölster-Holst, R.; et al. Infections in Dupilumab Clinical Trials in Atopic Dermatitis: A Comprehensive Pooled Analysis. Am. J. Clin. Dermatol. 2019, 20, 443-456. [CrossRef]

70. Lebwohl, M.; Rivera-Oyola, R.; Murrel, D.F. Should biolocs for psoriasis be interrupted in the era of COVID-19? J. Am. Acad. Dermatol. 2020, 82, 1217-1218. [CrossRef] 